\title{
SOURCE OF K-FELDSPARS AND KAOLINITIZATION IN ARKOSES OF WEST AND CENTRAL BOHEMIAN CONTINENTAL PERMO-CARBONIFEROUS
}

\author{
Jiřri Jiránek ${ }^{1 *}$, Josef Klomínský² \& Jana Jiránková ${ }^{1}$ \\ 1 Paprsková 4, 14200 Praha 4, Czech Republic; jirijiranekrndr@seznam.cz; jirankovajana@seznam.cz \\ 2 Czech Geological Survey, Klárov 3, 11821 Praha 1, Czech Republic; josef.klominsky@geology.cz \\ * Corresponding author
}

\begin{abstract}
The examined K-feldspars in arkoses of the continental Upper Carboniferous - Lower Permian of the West and Central Bohemian basins originated in the whole bed sequence (Duckmantian to Autunian; 314.2-297.1 Ma) from one source, which were so-called mountain granites of the older intrusive complex (OIC) of the Krušné hory Mts, as confirmed by the X-ray and geochemical analyses. The presence of feldspar clasts from other granitoids (Merklin and Louny massifs) was found only in the straight transgreding basal Carboniferous rocks. While other arkoses underwent synsedimentary and/or post-sedimentary kaolinization, in the deposits of Kaznějov and Horni Břiza (Nýrany Member of the Kladno Formation) pre-sedimentary kaolinization (sedimentation of sandstones and conglomerates with kaolinitic cement) occurred.
\end{abstract}

Keywords: Permo-Carboniferous, West and Central Bohemian basins, arkoses, Karlovy Vary Massif, K-feldspar, triclinicity, trace elements, kaolinization.

\section{INTRODUCTION}

The continental intermountainous Permo-Carboniferous basins of West and Central Bohemian areas (Plzeň, Manětín, Žihle, Radnice, Kladno-Rakovník and Mšeno-Roudnice basins) were filled with molasse sediments between Moscovian and Asselian (substage Duckmantian to Autunian; 314.2-297.1 Ma; Opluštil et al. 2016). Stratigraphically, four formations are involved: the Kladno Formation (Duckmantian - Cantabrian), subdivided into the Radnice (Duckmantian - Bolsovian) and the Nýřany members (Asturian - Cantabrian); the Týnec Formation (Barruelian - lowermost Saberian); the Slaný Formation (Saberian), subdivided into the Jelenice, Malesice and Otruby (or Ledce and Kounov) members; and the Líně Formation (uppermost Stephanian B - lower Autunian). Arkoses (sometimes kaolinized) are present in all the four formations. The aim of this work was to find the source of the arkosic feldspars.

The origin of alkali (potassium) feldspars in the Permo-Carboniferous arkoses has remained insufficiently solved to date. Study of arkoses in the Plzeň Basin, by Mašek (1962) found that "predom- inantly granites, whose composition had largely not been changed during destruction and denudation", participated in their origin. Pešek (1968) and Havlena \& Pešek (1975) provided also a series of geological proofs for the contribution of clasts of Proterozoic metamorphic slates and greywackes from the west. Nevertheless, Pešek's more recent works $(1994,2004)$ prefer a contribution from S-SE, particularly in the case of coarse grain clastics.

Petránek (1978) with Kukal (1984) discussed a source of arkosic feldspars. While Petránek doubted about the main source of feldspars in Variscean granitoids due to their insufficient denudation, according to Kukal (1984) the main source of arkosic feldspars were granitoid massifs. Klomínský et al. (1983) posited a contribution from the area of the Central Bohemian Pluton due to the spectrum of heavy minerals with detritic gold. Vlašímský (1986) also regarded granitoid rocks of the Central Bohemian Pluton, together with Cambrian sediments and volcanites, as an important source of the clastic material of arkoses of the Central Bohemian Permo-Carboniferous. 
Opluštil et al. (2016) and Martínek et al. (2017) discovered four significant hiatuses with duration of 1-3.6 Ma in the West and Central Bohemian Permo-Carboniferous, after which striking changes in the stratigraphy occured, and tried to connect them with tectonic and climatic phenomena. These hiatuses occur within a boundary that encompasses (1) between the Lower and Upper Radnice Member (313.7-312.6 Ma; lower Bolsovian); (2) between the Radnice and Nýřany members (311.9-308.3 $\mathrm{Ma}$; Leonian orogenetical phase in Bolsovian Asturian); (3) between the Kladno and Týnec formations (305.9-304.1 Ma; Asturian orogenetical phase in Cantabrian - Barruelian); and (4) between the Slaný and Líně formations (301.6$300.6 \mathrm{Ma}$; Intra-Stephanian orogenetical phase in Stephanian B). The second, third and last case were accompanied by striking changes of deposition centres and are therefore interpreted as tectonic events (tectonic activity was proven in the Central Bohemian, Litoměřice and Jáchymov faults; Martínek, Pešek \& Opluštil 2017). According to Martínek, Pešek \& Opluštil (2017), both tectonic movements and aridization took place in the boundaries of the Týnec and Slaný formations.

According to Pešek (1968), Havlena \& Pešek (1980) and Opluštil (2005) a deposition centre in the Plzeň Basin was a deeply cut river valley of NNE-SSW direction, filled with coarse grained sediments (conglomerates and arkoses), originating in the Radnice Member. After a hiatus on the boundary of the Radnice and Nýřany members, a change of contribution from NW direction took place. Even after a hiatus between the Kladno and Týnec formations, a contribution from the NW direction continuated in the Plzen Basin, while in the Kladno-Rakovník Basin, drained at the time of the Radnice Member sedimentation toward NW, the similar deposition centres were of NNE-SSW, NW-SE and E-W directions, active up to the Líně Formation (Opluštil 2005).

On the basis of $\mathrm{U}-\mathrm{Pb}$ geochronology of detritic zircon and monazite in the basin sediments, Žák et al. (2018) discovered mixing of material from local and distant sources of various age (Archeozoic Middle to Upper Carboniferous). During the consequent inversion of the palaeorelief, a quick uplift of the area to S and SW of today's basins 330-310 Ma ago (Visean - lowermost Moscovian) and a rapid baring of Moldanubian granitoids occurred to become a supplier of sedimentary filling of the basins, arisen freshly in N and NE 314-307 Ma ago (Radnice Member). Therefore, due to the study of detritic zircon and monazite, the opinion of the direction of the contribution changed by $180^{\circ}$ as against the previous publications by Opluštil (2005) and Martínek, Pešek \& Opluštil (2017).

\section{Composition of alkali feldspars in arkoses of Permo-Carboniferous basins and surrounding granitoids}

The origin of K-feldspars in arkoses of the Plzeň Basin from the neighbouring granitoid massifs was investigated by means of triclinicity (Kužvart

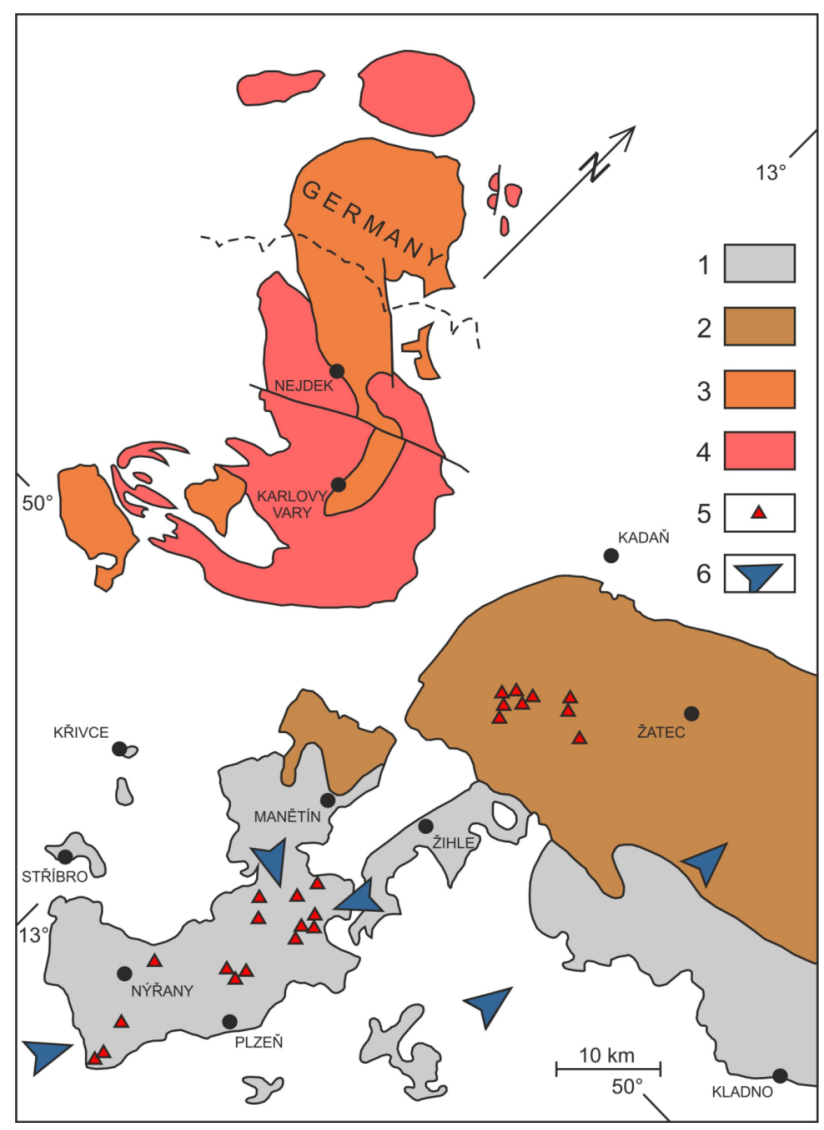

Figure 1. Position of the Upper Carboniferous - Lower Permian basins and the Karlovy Vary-Eibenstock granite Massif. 1 - Upper Carboniferous, Kladno Formation (conglomerate, sandstone, arkose, mudstone) and Týnec Formation (arkose with conglomerate intercalations, red sandstone and mudstone); 2 - Upper Carboniferous - Lower Permian, Lině Formation (red sandstone, arkose, conglomerate, mudstone); 3 - younger intrusive complex (YIC) of the Karlovy Vary-Eibenstock granite Massif; 4 - older intrusive complex (OIC) of the Karlovy Vary-Eibenstock granite Massif; 5 kaolin deposits; 6 -direction of transport of fluvial sediments into the Upper Carboniferous - Lower Permian basins. 
et al. 1975). For the investigation of the origin of K-feldspars in arkoses of Permo-Carboniferous basins, the results of Neužilová's research into triclinicity and geochemistry of K-feldspars from the Bor Massif granites (1971) and Kladruby Massif granites (1983), as well as analyses of $\mathrm{K}$-feldspars from granitoids of the Central Bohemian Pluton and other neighbouring granite massifs, granite porphyries, Teplice rhyolite, orthogneises and migmatites (Pivec 1970, Neužilová 1971, 1973a,b, Minařík 1974, 1975, Minařík \& Povondra 1976, Jiránek, unpublished data) have not been used so far.

To date, the most detailed X-ray study of the structural arrangement (triclinicity), the molecular composition $\operatorname{Or}(\mathrm{AbAn})$ and the chemistry of trace elements ( $\mathrm{Ba}, \mathrm{Sr}, \mathrm{Pb}, \mathrm{Rb}, \mathrm{Sn}, \mathrm{Be}$ ) has been carried out on 224 samples of phenocrysts of K-feldspars of granites in the Nejdek part of the Karlovy Vary-Eibenstock granite Massif (Jiránek 1982a, 1983). This largest granite body of the West Krušné hory Mts. composite pluton (Klomínský et al. 2010) occurs only $20 \mathrm{~km} \mathrm{NW}$ of today's rims of the Carboniferous basins (Figure 1). The upper part of granites of the older intrusive complex (OIC) is disturbed by intrusion of the younger intrusive complex (YIC) (Lange et al. 1972, Absolonová \& Matoulek 1978, Breiter et al. 1991, Breiter et al. 1991). The intrusion of these posttectonic granites reached a depth of ca $2-4 \mathrm{~km}$ under the original surface (Thomas et al. 1991). According to the results of geochronological analyses the age of the OIC granites lies in the range from 330 to $305 \mathrm{Ma}$, while YIC granites are 25 milion years younger (Breiter 2012). The OIC group of so-called mountain granites (mesocratic peraluminic monzo- to syenogranites) is represented mainly by medium granular (porphyric) biotitic granite to granodiorite (Nejdek granite). YIC granites form a varied group of intensively fractionated granites here accompanied by tin mineralization (Štemprok 1986, Breiter 2001).

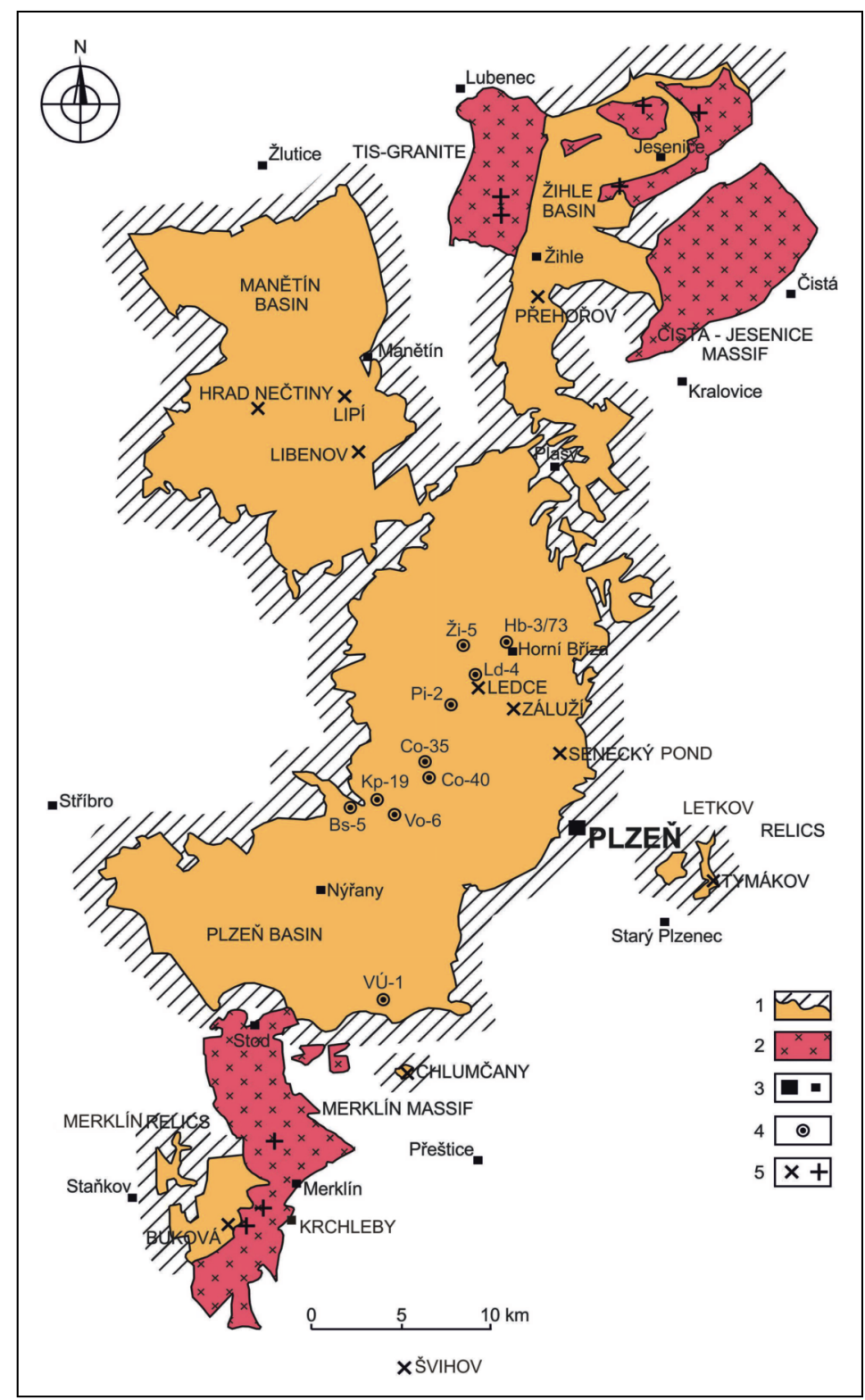

Figure 2. Position of the studied samples of K-feldspars of arkoses in the Plzeñ, Manětín and Žihle basins, in the Letkov Carboniferous relics and the Merklin Carboniferous relics of the West Bohemian continental Carboniferous. 1 - boundary of Carboniferous; 2 - bodies of granitoids; 3 - towns and villages; 4 - boreholes studied; 5 - studied exposures of Carboniferous arkoses $(x)$ and granitoids (+).

The strong predominance of perthitic orthoclases $(\Delta<0.2)$ and minimal values of $\mathrm{K}$-feldspars triclinicity in granites of the OIC as well as the YIC is a result of magmatic origin under high temperatures and relatively rapid crystallization (Jiránek 1982a) in the vicinity of their original roof. In the case of the granites of YIC, their quick solidification had a subvolcanic character (Rojík 2006). 


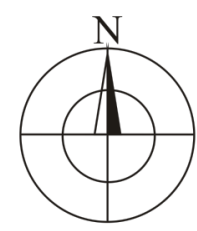

- Budyně nad Ohří

\section{○ Mt-1}

- Mšené Lázně

- Vraný

$$
\text { - Šlapanice }
$$

Zlonice

- Černuc

Velvary

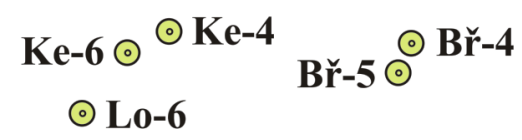

Slaný

Smečno $\quad$ Pchery

Kladno

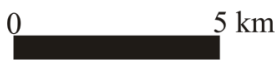

Figure 3. Position of the sampled boreholes in the surroundings of the town of Slany in the Kladno-Rakovnik Basin of the Central Bohemian continental Permo-Carboniferous. (For explanations see Figure 2.)

The published data on the structural arrangement (triclinicity) and the content of trace elements of K-feldspars of the granitoid massifs in the surroundings of the West and Central Bohemi- an Permo-Carboniferous basins were correlated with the results of research into clastic relics of K-feldspars from Permo-Carboniferous arkoses (Figure $5 \mathrm{a}, \mathrm{b}, \mathrm{c}$ ). The collection of 41 samples of K-feldspars from arkoses represents the whole area of the West and Central Bohemian Upper Carboniferous - Lower Permian basins between the towns of Struíbro and Velvary both in the horizontal and vertical (stratigraphic) range (Figures 2, 3 and 4).

\section{METHODS}

The separated K-feldspars from Permo-Carboniferous arkoses were X-ray (triclinicity $\Delta, A b A n_{\text {solid }}$, $A b f_{\text {free }}$ ) and geochemically ( $\left.\mathrm{Ba}, \mathrm{Sr}, \mathrm{Pb}, \mathrm{Rb}\right)$ examined. The X-ray study of alkali feldspars was carried out on the X-ray difractometer Müller Mikro 111 in ÚÚG (Czech Geological Service) in Prague by the method described by Jiránek (1979). Neither low grade of weathering nor the initial kaolinization of $\mathrm{K}$-feldspars influence the X-ray measured values. $\mathrm{X}$-ray triclinicity $\Delta$ was measured from the differences of diffraction lines 131 and $1 \underline{3} 1$ by the classical method of Goldsmith \& Laves (1954): $\Delta=12.5$ $\left(d_{131}-d_{131}\right)$, where 0 corresponds to sanidine or orthoclase, $0.2-0.9$ to transitional microcline and 1 to maximal microcline. The content of AbAn component in a solid solution $\left(A b A n_{\text {solid }}\right)$ was determined from a position of diffraction line 201 of K-feldspar according to the graph of Jones, Nesbitt \& Slade (1969), a content of exsoluted Ab component $\left(A b_{\text {free }}\right)$ was determined according to the graph constructed by Jiránek (1979) on the basis of ratios of intensities (measured as the height/width ratio of half the heights of the corresponding diffraction peaks) of diffraction lines 201 of K-feldspar and 201 of albite. The contents of trace elements typical for $\mathrm{K}$-feldspars $(\mathrm{Ba}, \mathrm{Sr}, \mathrm{Pb}, \mathrm{Rb})$ were determined by AAS method in the laboratories of ÚÚG (Czech Geological Service) in Prague.

Figure 4. Simplified geological profiles of the studied boreholes in the Plzeñ and Kladno-Rakounik basins with the points of sampling. 1 - Quaternary; 2 - Upper Cretaceous; 3 - Lower Permian - Upper Carboniferous, Líně Formation; 4 - Upper Carboniferous, Slaný Formation, Otruby (Ledce + Kounov) members; 5 - Slaný Formation, Malesice Member; 6 - Slaný Formation; Jelenice Member; 7 - Týnec Formation; 8 - Kladno Formation, Nýrany Member; 9 - Kladno Formation, Radnice Member; 10 - Neoproterozoic; 11 - granitoids (undifferentiated); 12 - loss of core; 13 - drawn samples; 14 - K-feldspars enrichment. 
Jiří Jiránek, Josef Klomínský \& Jana Jiránková, Source of K-feldspars and kaolinitization in arkoses of West and central Bohemian continental Permo-Carboniferous

Figure 4.

\section{PLZEŇ BASIN}
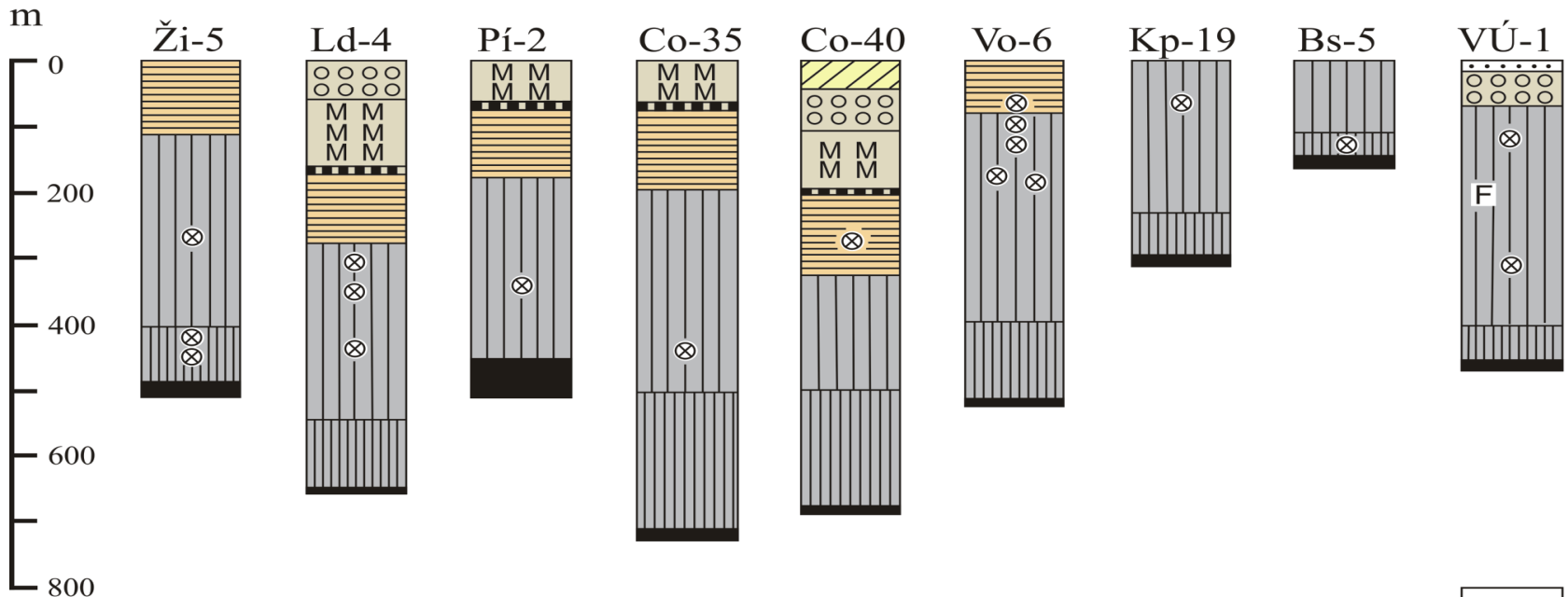

\section{KLADNO-RAKOVNÍK BASIN}

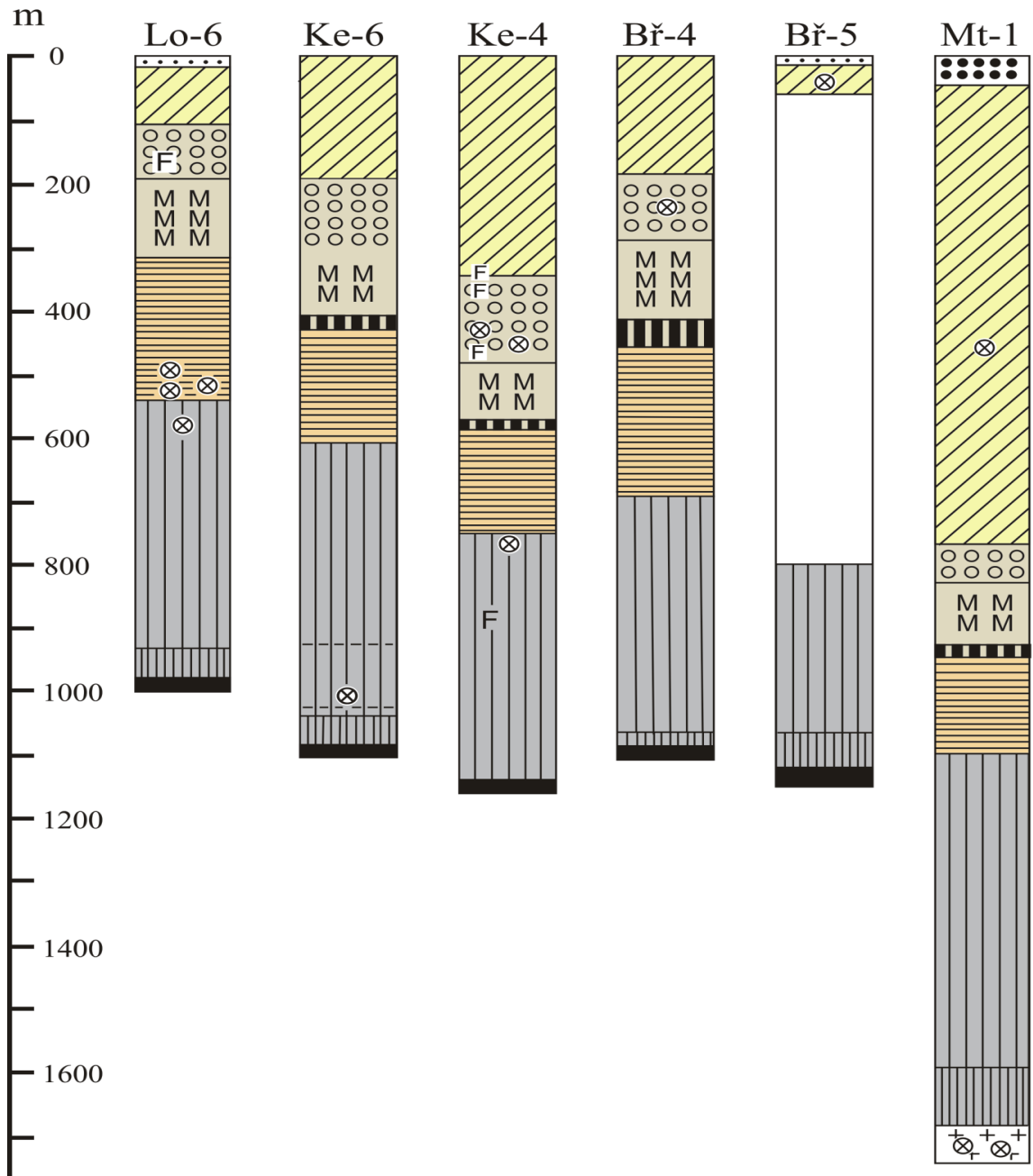

Mt-1

2

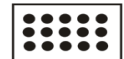

3

4 \begin{tabular}{lllll}
0 & 0 & 0 & 0 \\
0 & 0 & 0 & 0 \\
\hline
\end{tabular}

$5 \mathrm{M} \mathrm{M}$

6

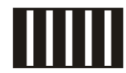

7

8

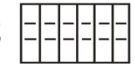

9

10

$1 1 \longdiv { + + + }$

Líně Formation

12

Slaný Formation

Týnec Formation

13

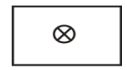

Kladno Formation

14 


\section{RESULTS}

The results of X-ray measurements and chemical analyses of handly separated K-feldspars from PermoCarboniferous arkoses are stated in Table 1.

Table 1. Results of measurement of individual samples of K-feldspars in Carboniferous arkoses (Composition of K-feldspar, $A b A n_{\text {solid }}$ and $A b_{\text {free }}$ in \%; $\mathrm{Ba}, \mathrm{Sr}, \mathrm{Pb}$ and $\mathrm{Rb}$ in ppm; $\Delta=$ triclinicity; $\mathrm{Kf}=\mathrm{K}$-feldspar; Or = orthoclase; Mi = microcline; $\mathrm{Ab}=$ albite; $\mathrm{An}=$ anorthite).

\begin{tabular}{|c|c|c|c|c|c|c|c|c|c|}
\hline $\mathbf{N}$ & Locality/Borehole & Kf & $\Delta \mathbf{M i}$ & $\boldsymbol{A b A n _ { \text { solid } }}$ & $\boldsymbol{A} \boldsymbol{b}_{\text {free }}$ & $\mathbf{B a}$ & Sr & $\mathbf{P b}$ & $\mathbf{R b}$ \\
\hline 1 & Ži-5 (444.2) & Or100 & & 23 & 0 & 2200 & 280 & 91 & 300 \\
\hline 2 & Ži-5 (412.35) & Or70 Mi30 & 0,74 & 18 & 0 & 1900 & 170 & 92 & 317 \\
\hline 3 & Ži-5 (266.1) & Or80 Mi20 & 0,77 & 18 & 0 & 2100 & 220 & 87 & 380 \\
\hline 4 & Ld-4 (439.1) & Or80 Mi20 & 0,79 & 18,5 & 0 & 2300 & 220 & 82 & 393 \\
\hline 5 & Ld-4 (350.2) & Or100 & & 18,5 & 0 & 2800 & 240 & 86 & 316 \\
\hline 6 & Ld-4 (309.25) & Or100 & & 16 & 0 & 2000 & 230 & 92 & 370 \\
\hline 7 & Pí-2 (343.85) & Or100 & & 20,5 & 0 & 3000 & 280 & 76 & 395 \\
\hline 8 & Co-35 (443.7) & Or100 & & 16 & 0 & 2500 & 310 & 98 & 337 \\
\hline 9 & Co-40 (272.5) & Or100 & & 18 & 0 & 2700 & 280 & 99 & 348 \\
\hline 10 & Vo-6 (185.5) & Or100 & & 27,5 & 0 & 3341 & 303 & 87 & 368 \\
\hline 11 & Vo-6 (176.1) & Or100 & & 31 & 0 & 2866 & 260 & 91 & 367 \\
\hline 12 & Vo-6 (128.7) & Or95 Mi5 & 0,82 & 32 & 0 & 2696 & 288 & 83 & 356 \\
\hline 13 & Vo-6 (101.9) & Or95 Mi5 & 0,70 & 30 & 0 & 2150 & 213 & 74 & 428 \\
\hline 14 & Vo-6 (67.3) & Or100 & & 30,5 & 0 & 2884 & 314 & 85 & 359 \\
\hline 15 & Kp-19 (69.1) & Or100 & & 29 & 0 & 2374 & 222 & 82 & 458 \\
\hline 16 & Bs-5 (131.3) & Or100 & & 29 & 0 & 1863 & 184 & 81 & 426 \\
\hline 17 & VÚ-1 (311.3) & Or100 & & 32 & 0 & 1729 & 211 & 93 & 402 \\
\hline 18 & VÚ-1 (115.5) & Or100 & & 32 & 0 & 2275 & 211 & 90 & 375 \\
\hline 19 & Senecký pool & Or100 & & 24 & 0 & 2200 & 300 & 90 & 330 \\
\hline 20 & Chlumčany & Or100 & & 24 & 0 & 1900 & 310 & 121 & 394 \\
\hline 21 & HB 3/73 & Or50 Mi50 & 0,83 & 21 & 0 & 1800 & 160 & 78 & 351 \\
\hline 22 & Záluží & Or100 & & 20 & 0 & 2000 & 200 & 84 & 372 \\
\hline 23 & Ledce & Or90 Mi10 & 0,66 & 20,5 & 0 & 3200 & 410 & 100 & 301 \\
\hline 24 & Švihov, building stone & Or100 & & 33 & 0 & 2508 & 295 & 98 & 346 \\
\hline 25 & Buková & Or100 & & 33 & 0 & 2571 & 259 & 87 & 342 \\
\hline 26 & Tymákov & Or80 Mi20 & 0,80 & 20 & 0 & 1900 & 590 & 106 & 341 \\
\hline 27 & Lipí & Or100 & & 17,5 & 0 & 1800 & 190 & 83 & 362 \\
\hline 28 & Libenov & Or60 Mi40 & 0,74 & 18 & 0 & 2800 & 270 & 101 & 313 \\
\hline 29 & Nečtiny & Or100 & & 18 & 0 & 2800 & 300 & 95 & 316 \\
\hline 30 & Přehořov & Or70 Mi30 & $0,67>0,99$ & 20 & 0 & 1900 & 150 & 60 & 231 \\
\hline 31 & Bř-4 (239.3) & Or100 & & 29,5 & 0 & 2687 & 290 & 73 & 375 \\
\hline 32 & Bř-5 (48.0-50.0) & Or100 & & 19 & 0 & 1900 & 250 & 78 & 328 \\
\hline 33 & $\mathrm{Ke}-4(762.1)$ & Or60 Mi40 & 0,84 & 17 & 6,3 & 1935 & 240 & 67 & 320 \\
\hline 34 & $\mathrm{Ke}-4(444.7)$ & Or90 Mi10 & 0,76 & 32 & 7,0 & 1326 & 161 & 87 & 352 \\
\hline 35 & $\mathrm{Ke}-4(432.1)$ & Or70Mi30 & 0,59 & 26 & 6,7 & 1155 & 136 & 68 & 421 \\
\hline 36 & $\mathrm{Ke}-6(1008.5)$ & Or100 & & 28 & 0 & 2239 & 324 & 68 & 268 \\
\hline 37 & Lo-6 (578.6) & Or95 Mi5 & 0,76 & 27,5 & 0 & 2177 & 224 & 92 & 378 \\
\hline 38 & Lo-6 (530.2) & Or90 Mi10 & 0,86 & 29,5 & 0 & 2589 & 268 & 106 & 346 \\
\hline 39 & Lo-6 (513.5) & Or90 Mi10 & 0,80 & 35 & 0 & 2768 & 276 & 94 & 326 \\
\hline 40 & Lo-6 (491.0) & Or95 Mi5 & 0,81 & 29,5 & 0 & 2383 & 241 & 91 & 297 \\
\hline 41 & Mt-1 (455.5) & Or100 & & 29 & 6,5 & 2221 & 245 & 82 & 258 \\
\hline
\end{tabular}


Triclinicity. All 41 samples analysed are orthoclases, sometimes with an admixture of transitional to maximal microcline with $\Delta=0.59-0.99$. In $59 \%$ of samples, there is a pure orthoclase, in $20 \%$ an orthoclase with an admixture of $10 \%$ of microcline, in $14 \%$ an orthoclase with an admixture of $30 \%$ of microcline and only in $7 \%$ of the cases the content of microcline reaches up to $50 \%$. In one case (a sample of Přehořov in the Žihle Basin) there are, besides prevailing orthoclase, two different microclines with $\Delta=0.67$ and 0.99 . (For comparison: Among 123 samples of K-feldspars in the OIC granites of the Karlovy VaryEibenstock Massif, there are according to Jiránek (1982a) $83 \%$ of pure orthoclase, $12 \%$ of orthoclase in mixture with $20-80 \%$ of transitional microcline with $\Delta=0.44-0.73$, and $5 \%$ of pure transitional microcline with $\Delta=0.19-0.71$.)

Content of AbAn component in the solid solution $\left(A b A n_{\text {solid }}\right)$ ranges between $16-35 \%$ (average $24.6 \%$ ).

Content of exsoluted $A b$ component $\left(A b_{\text {free }}\right)$ is equal to zero in $95 \%$ of samples, which indicates that the original perthitic albite was secondarily leached off, because albites and plagioclases undergo kaolinization earlier than K-feldspars. Only four samples from two boreholes in the KladnoRakovník Basin, three from the borehole Kralovice Ke-4 (depth 432.1-762.1 m; Otruby Member of the Slaný Formation and Nýřany Member of the Kladno Formation) and one from the borehole Martiněves Mt-1 (depth 455.5 m; Líně Formation), contain $6.3-7.0 \%$ of $A b_{\text {free }}$ and indicate then freshness of feldspars at greater depths.

Contents of $B a$ range between 1,155-3,341 ppm (average 2,303 ppm), contents of $S r$ 136-590 ppm (average $257 \mathrm{ppm}$ ), contents of $\mathrm{Pb} 60-121 \mathrm{ppm}$ (average $87 \mathrm{ppm}$ ) and contents of $R b$ 231-458 ppm (average $350 \mathrm{ppm}$ ).

The values of triclinicity and the trace elements contents in K-feldspars of Permo-Carboniferous arkoses for individual basins are stated in Table 2, together with the values for K-feldspars in the OIC of the Karlovy Vary Massif. The same results for the Kladno, Týnec, Slaný and Líně formations, are

Table 2. Summary of results of measurement of K-feldspars in Permo-Carboniferous arkoses for individual basins in comparison with K-feldspars of the older intrusive complex (OIC, mountain granites) of the Nejdek part of the Karlovy Vary Massif ( $n=$ number of samples; $\phi=$ average; $\Delta=$ triclinicity, Or = orthoclase, $\mathrm{Mi}=$ microclase, $\mathrm{Ab}=$ albite, An $=$ anorthite).

\begin{tabular}{|c|c|c|c|c|c|c|}
\hline & Triclinicity & $\boldsymbol{A b A n _ { \text { solid } }}$ & Ba (ppm) & Sr (ppm) & $\mathrm{Pb}$ (ppm) & Rb (ppm) \\
\hline $\begin{array}{l}\text { Plzeň Basin } \\
(n=26)\end{array}$ & $\begin{array}{c}59 \% \text { Or100 } \\
41 \% \text { Or95 Mi5 to } \\
\text { Or50 Mi50 } \\
\Delta 0,66-0,83 \\
\phi=\mathbf{0 , 7 6}\end{array}$ & $\begin{array}{c}16-33 \% \\
\boldsymbol{\phi}=\mathbf{2 4 , 4} \%\end{array}$ & $\begin{array}{l}1700-3341 \\
\phi=\mathbf{2 3 7 5}\end{array}$ & $\begin{array}{c}160-590 \\
\phi=\mathbf{2 6 8}\end{array}$ & $\begin{array}{l}74-121 \\
\phi=\mathbf{9 0}\end{array}$ & $\begin{array}{l}330-458 \\
\phi=\mathbf{3 6 4}\end{array}$ \\
\hline $\begin{array}{l}\text { Manětín + Žihle } \\
\text { basins } \\
(n=4)\end{array}$ & $\begin{array}{c}50 \% \text { Or100 } \\
50 \% \text { Or70 Mi30 } \\
\text { to Or60 Mi40 } \\
\Delta 0,67-0,99 \\
\boldsymbol{\phi}=\mathbf{0 , 8 0}\end{array}$ & $\begin{array}{l}17,5-20 \% \\
\phi=18,4 \%\end{array}$ & $\begin{array}{l}1800-2800 \\
\phi=\mathbf{2 3 2 5}\end{array}$ & $\begin{array}{l}150-300 \\
\phi=\mathbf{2 2 8}\end{array}$ & $\begin{array}{l}60-101 \\
\phi=85\end{array}$ & $\begin{array}{l}231-262 \\
\phi=\mathbf{3 0 6}\end{array}$ \\
\hline $\begin{array}{l}\text { Kladno-Rakovník } \\
\text { Basin } \\
(n=11)\end{array}$ & $\begin{array}{c}36 \% \text { Or100 } \\
64 \% \text { Or95 Mi5 to } \\
\text { Or60 Mi40 } \\
\Delta 0,59-0,86 \\
\phi=\mathbf{0 , 7 7} \\
\end{array}$ & $\begin{array}{c}17-35 \% \\
\phi=\mathbf{2 7 , 5} \%\end{array}$ & $\begin{array}{l}1155-2768 \\
\phi=\mathbf{2 1 2 5}\end{array}$ & $\begin{array}{l}136-324 \\
\phi=\mathbf{2 4 1}\end{array}$ & $\begin{array}{l}67-106 \\
\phi=82\end{array}$ & $\begin{array}{l}258-421 \\
\phi=\mathbf{3 3 4}\end{array}$ \\
\hline $\begin{array}{l}\boldsymbol{\Sigma} \text { Upper } \\
\text { Carboniferous } \\
(n=41)\end{array}$ & $\begin{array}{c}59 \% \text { Or100 } \\
41 \% \text { Or95 Mi5 to } \\
\text { Or50 Mi50 } \\
\Delta 0,59-0,99 \\
\phi=\mathbf{0 , 7 7}\end{array}$ & $\begin{array}{c}16-35 \% \\
\boldsymbol{\phi}=\mathbf{2 4 , 6} \%\end{array}$ & $\begin{array}{l}1155-3341 \\
\phi=\mathbf{2 3 0 3}\end{array}$ & $\begin{array}{l}136-590 \\
\phi=\mathbf{2 5 7}\end{array}$ & $\begin{array}{l}60-121 \\
\phi=87\end{array}$ & $\begin{array}{l}231-458 \\
\boldsymbol{\phi}=\mathbf{3 5 0}\end{array}$ \\
\hline $\begin{array}{l}\text { Karlovy Vary } \\
\text { Massif } \\
(\text { OIC) } \\
(n=123) \\
\end{array}$ & $\begin{array}{c}82 \% \text { Or } 100 \\
11 \% \text { OrMi } \\
\Delta 0,44-0,73 \\
\phi=\mathbf{0 , 5 6}\end{array}$ & $\begin{array}{l}7-24 \% \\
\phi=13 \%\end{array}$ & $\begin{array}{l}<120-4800 \\
\phi=\mathbf{2 3 4 9}\end{array}$ & $\begin{array}{l}100-500 \\
\phi=\mathbf{3 6 0}\end{array}$ & $\begin{array}{l}28-104 \\
\phi=68\end{array}$ & $\begin{array}{c}44-400 \\
\boldsymbol{\phi}=\mathbf{3 0 0}\end{array}$ \\
\hline
\end{tabular}


Table 3. Summary of results of measurement of K-feldspars in Permo-Carboniferous arkoses for individual members and formations of the West and Central Bohemian basins ( $n=$ number of samples; $\phi=$ average; $\Delta=$ triclinicity, Or $=$ orthoclase, $\mathrm{Mi}=$ microcline, $\mathrm{Ab}=$ albite, $\mathrm{An}=$ anorthite $)$.

\begin{tabular}{|c|c|c|c|c|c|c|}
\hline & Triclinicity $\Delta$ & $\boldsymbol{A b A n _ { \text { solid } }}$ & Ba (ppm) & Sr (ppm) & $\mathbf{P b}$ (ppm) & Rb (ppm) \\
\hline $\begin{array}{l}\text { Radnice } \\
\text { Member, } \\
\text { Kladno } \\
\text { Formation } \\
(n=4)\end{array}$ & $\begin{array}{c}75 \% \text { Or100 } \\
25 \% \text { Or70 } \\
\text { Mi30 } \\
\phi=\mathbf{0 . 7 4}\end{array}$ & $\begin{array}{r}18-29 \% \\
\phi=\mathbf{2 3 . 5} \%\end{array}$ & $\begin{array}{l}1863-2200 \\
\phi=\mathbf{2 0 4 1}\end{array}$ & $\begin{array}{l}170-300 \\
\phi=\mathbf{2 3 4}\end{array}$ & $\begin{array}{c}81-92 \\
\phi=89\end{array}$ & $\begin{array}{l}300-426 \\
\phi=\mathbf{3 4 3}\end{array}$ \\
\hline $\begin{array}{l}\text { Nýřany } \\
\text { Member, } \\
\text { Kladno } \\
\text { Formation } \\
(n=20)\end{array}$ & $\begin{array}{c}55 \% \text { Or100 } \\
45 \% \text { Or95 Mi5 } \\
\text { to Or60 Mi40 } \\
\phi=\mathbf{0 . 7 0}-\mathbf{0 . 8 4}\end{array}$ & $\begin{array}{l}16-35 \% \\
\phi=\mathbf{2 5} \%\end{array}$ & $\begin{array}{l}1729-3341 \\
\phi=\mathbf{2 3 9 4}\end{array}$ & $\begin{array}{l}211-590 \\
\phi=\mathbf{2 7 3}\end{array}$ & $\begin{array}{l}67-121 \\
\phi=\mathbf{9 0}\end{array}$ & $\begin{array}{l}268-458 \\
\phi=\mathbf{3 5 9}\end{array}$ \\
\hline $\begin{array}{l}\text { Týnec } \\
\text { Formation } \\
(n=9)\end{array}$ & $\begin{array}{c}45.5 \% \text { Or100 } \\
54.5 \% \text { Or95 } \\
\text { Mi5 to Or50 } \\
\text { Mi50 } \\
\phi=\mathbf{0 . 7 0}-\mathbf{0 . 8 4}\end{array}$ & $\begin{array}{c}17.5-33 \% \\
\phi=\mathbf{2 3} \%\end{array}$ & $\begin{array}{l}1800-2884 \\
\phi=\mathbf{2 2 8 9}\end{array}$ & $\begin{array}{r}150-314 \\
\phi=\mathbf{2 2 6}\end{array}$ & $\begin{array}{l}60-101 \\
\phi=83\end{array}$ & $\begin{array}{r}231-428 \\
\phi=\mathbf{3 4 5}\end{array}$ \\
\hline $\begin{array}{l}\text { Otruby } \\
\text { (Ledce+Kounov) } \\
\text { members, } \\
\text { Slaný } \\
\text { Formation } \\
(n=3) \\
\end{array}$ & $\begin{array}{c}33 \% \text { Or100 } \\
67 \% \text { Or90 } \\
\text { Mi10 to Or70 } \\
\text { Mi30 } \\
\phi=\mathbf{0 . 5 9}-\mathbf{0 . 7 6} \\
\end{array}$ & $\begin{array}{l}26-32 \% \\
\boldsymbol{\phi}=\mathbf{2 9} \%\end{array}$ & $\begin{array}{c}1155-2687 \\
\boldsymbol{\phi}=\mathbf{1 7 2 3}\end{array}$ & $\begin{array}{l}136-290 \\
\phi=196\end{array}$ & $\begin{array}{r}68-87 \\
\phi=76\end{array}$ & $\begin{array}{l}352-421 \\
\phi=383\end{array}$ \\
\hline $\begin{array}{l}\text { Líně } \\
\text { Formation } \\
(n=4)\end{array}$ & $\begin{array}{c}75 \% \text { Or100 } \\
25 \% \text { Or90 } \\
\text { Mi10 } \\
\phi=\mathbf{0 . 6 6}\end{array}$ & $\begin{array}{l}18-29 \% \\
\phi=22 \%\end{array}$ & $\begin{array}{l}1900-3200 \\
\phi=\mathbf{2 5 3 0}\end{array}$ & $\begin{array}{l}245-410 \\
\phi=\mathbf{2 0 1}\end{array}$ & $\begin{array}{l}78-100 \\
\phi=89\end{array}$ & $\begin{array}{l}258-328 \\
\phi=\mathbf{3 0 1}\end{array}$ \\
\hline
\end{tabular}

stated in Table 3. No significant differences between K-feldspars of individual areas (basins) and formations were found, and therefore, in seeking the primary source of K-feldspars it was possible to use the statistical sets for the West and Central Bohemian Permo-Carboniferous as a whole.

The structural properties and trace element content of K-feldspars in Permo-Carboniferous arkoses were compared with the structural properties and trace element content in 63 separated K-feldspars phenocrysts from mountain granites (OIC) of the Nejdek part of the Karlovy Vary Massif (Jiránek 1982a, 1983). For the comparison of Kfeldspars in Permo-Carboniferous arkoses and the Karlovy Vary Massif (both the OIC and YIC), the binary $\mathrm{Ba}$ and $\mathrm{Rb}$ diagram (Figure $5 \mathrm{c}$ ), the elements entering into the K-feldspars lattice preferentially in the extreme phases of their crystallization ( $\mathrm{Ba}$ in the oldest and $\mathrm{Rb}$ in the youngest types of granites), was used.

\section{DISCUSSION}

The appearance of K-feldspars in Permo-Carboniferous arkoses (white to pink, originally big phenocrysts with rare inclusions of quartz and biotite, sporadically muscovite) and their structural arrangement and trace elements contents point to the intrusive origin. The dimensions of K-feldspars grains even at a considerable distance from the possible sources show that their origin must have been in porphyric types of granitoids. The uniformity of all the examined K-feldspars of the West and Central Bohemian Upper Carboniferous Lower Permian arkoses indicates that they originated from one single source. The supply of K-feldspars to the whole investigated area from this source occurred during the period 17.1 Ma (314.2297.1 Ma; Moscovian-Asselian), during which 7.5 Ma represented the sedimentation hiatuses, indicates the long-term exposure of a large relatively homogeneous granite massif. 


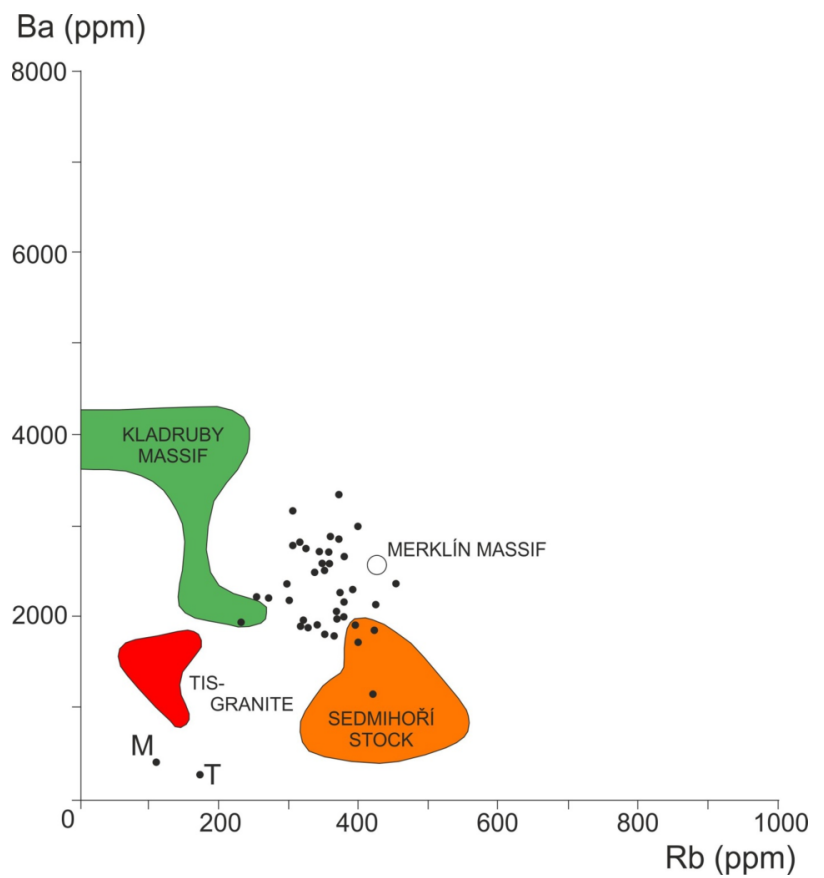

Figure 5a. Graphs of Ba/Rb (ppm) contents of $K$-feldspars in Permo-Carboniferous arkoses in comparison with fields of their contents in the Kladruby Massif (Neužilová 1983), Sedmihoři Stock (Neužilová 1983), Merklín Massif and the Tis granite of the Louny Massif (Jiránek, unpublished data). The points mark the studied K-feldspars in Permo-Carboniferous arkoses, $M=$ sample of K-feldspar in the Merklin Massif by Krchleby, $T$ = sample of K-feldspar in the Tis granite of the Louny Massif from the borehole $M t-1(1,680.5 \mathrm{~m})$.

The values of K-feldspars triclinicity, without the parallel geochemical data, are not an unambiguous source indicator, because they do not differ among the various granitoid rocks in such a range as the contents of trace elements. A good many candidates for the source of K- feldspars in PermoCarboniferous arkoses, chosen on the basis of triclinicity values and of chronologically corresponding age towards Permo-Carboniferous sediments, can be excluded by determination of trace elements typical for the various phases of K-feldspars genesis, particularly geochemically opposite $\mathrm{Ba}$ and $\mathrm{Rb}$ (Figures 5a, b, c).

Figure 5c. Graphs of Ba/Rb (ppm) contents of K-feldspars in Permo-Carboniferous arkoses in comparison with fields of their contents in granitoids of the older (OIC) and younger (YIC) intrusive complex of the Krušné hory Mts. (Jiránek 1983) and in granite porphyries of the Fláje Massif (Jiránek, unpublished data). The points mark the studied $K$-feldspars in Permo-Carboniferous arkoses, $M=$ sample of K-feldspar in the Merklin Massif by Krchleby, $T=$ sample of K-feldspar in the Tis granite of the Louny Massif from the borehole $M t-1(1,680.5 \mathrm{~m})$.

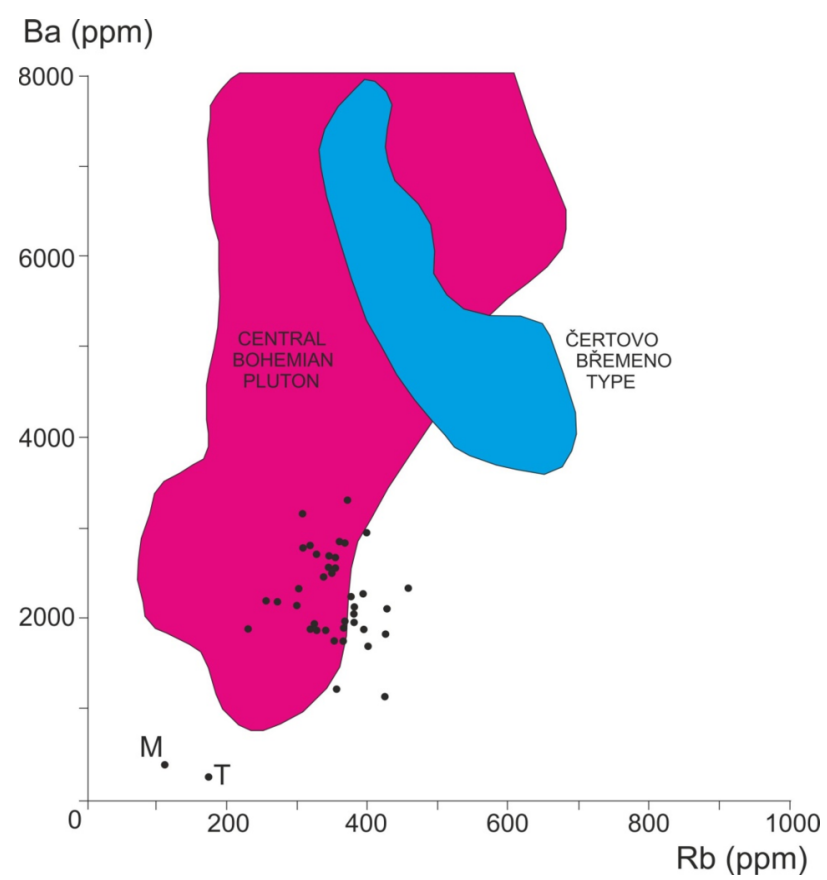

Figure 5b. Graphs of Ba/Rb (ppm) contents of K-feldspars in Permo-Carboniferous arkoses in comparison with fields of their contents in the granitoids of the Central Bohemian Pluton (Minařík 1974, 1975; Neužilová 1973a,b; Jiránek, unpublished data; the Certovo Bremeno type according to Minař́k and Povondra 1976). The points mark the studied $K$-feldspars in Permo-Carboniferous arkoses, $M=$ sample of K-feldspar in the Merklin Massif by Krchleby, $T=$ sample of $K$-feldspar in the Tis granite of the Louny Massif from the borehole $M t-1(1,680.5 \mathrm{~m})$.

Figure 5c.

$\mathrm{Ba}(\mathrm{ppm})$

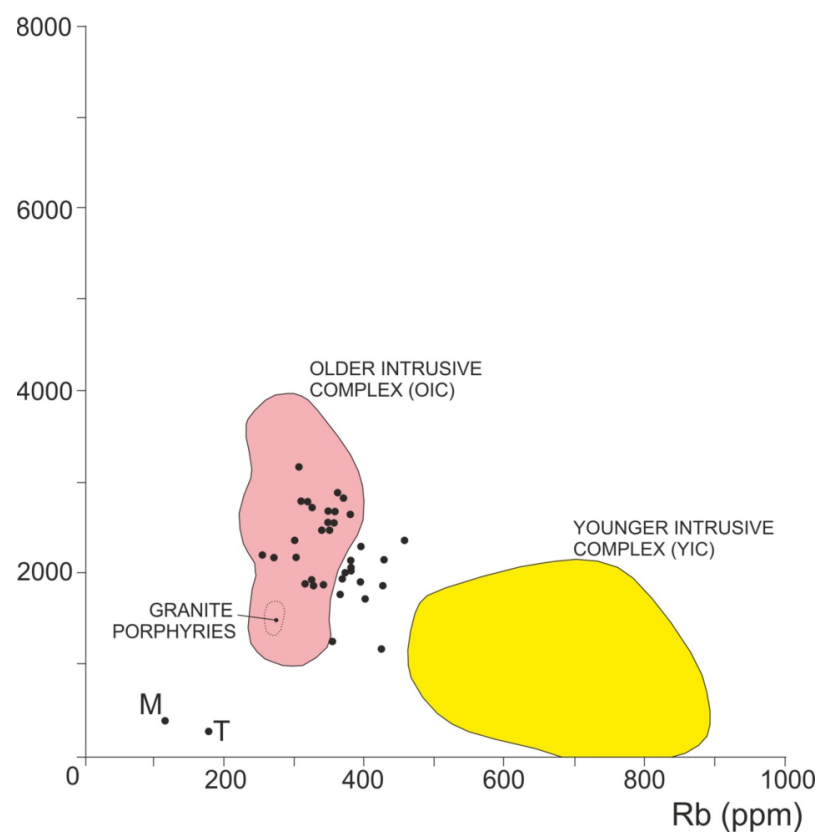


The Merklín Massif and Tis granite of the Louny Massif, on which the Carboniferous sediments directly transgrade, were the only local and chronologically closely limited sources of arkoses feldspars on the basis of the Carboniferous in the respective areas. A sample drawn from the basis of the transgrading Nýřany Member in the Merklín Carboniferous relics $2 \mathrm{~km} \mathrm{NE}$ of Krchleby points to the dissimilar character of K-feldspars of the Merklín Massif (Or100Mi0; $A b A n_{\text {solid }} 31 \% ; A b_{\text {free }}$ 0.5 \%; Ba 439 ppm; Sr 18 ppm; Pb 34 ppm; Rb 114 ppm; Figures 5a,b,c), and similarly the sample of K-feldspars from the borehole Martiněves Mt-1 from the basis of Radnice Member of the Kladno Group, transgrading over Tis granite (Louny Massif) at a depth of 1,680.5 m (Ba 296 ppm; Sr 46 ppm; Pb 41 ppm; Rb 173 ppm; Figures 5a, b, c). Moreover, K-feldspars of the Čistá-Jesenice Massif (a component of the Louny Massif) are, according to Kužvart et al. (1975), microclines with $\Delta=$ 0.78-0.93. K-feldspars of the Stod Massif, according to the same authors, also have increased triclinicity ( $\Delta=0.25-0.36$ ). Likewise K-feldspars of the Kladruby Massif (360-330 Ma) have $57.5 \%$ microclines with $\Delta=0.63-1.00$ (Neužilová 1983) and besides they have different trace chemistry (higher $\mathrm{Ba}$ and lower Rb; Jiránek, unpublished). Therefore, the granitoids of the Merklín, Stod and Kladruby Massifs, or an extensive body of Tis granites of the Louny Massif, could not have been a significant source of K-feldspars of Permo-Carboniferous arkoses (Figure 5a).

Owing to the various values of the measured parameters, the majority of the Central Bohemian Pluton including the Čertovo Břemeno type or the Červená type with microclines (Figure 5b), the YIC granites of the Krušné hory Mts. pluton (Figure 5c), granite porphyries (Fláje Massif), Teplice rhyolite, Lužice granites and orthogneisses, granites, orthogneisses and migmatites of the Moldanubicum can be also excluded as a possible source.

Trace elements contents close to those of K-feldspars in Permo-Carboniferous arkoses as well as being found in the granites of the OIC of the Karlovy Vary Massif, are exhibited by K-feldspars of the marginal type of the Central Bohemian Pluton and Moldanubian granites of Weinsberg and Eisgarn types. These could hardly serve as a source material of arkoses owing to the limited dimen- sions of bodies in the case of the marginal type, and, in the case of Moldanubian granites, owing of the fact that they might have only become a possible source during the sedimentation of the Radnice Member (as shown by results from the works of Žák et al. 2018), despite the greater length of transport towards the Kladno-Rakovník Basin. The marginal type of the Central Bohemian Pluton could provide a source of K-feldspars only in the case that it would form an extensive mantle of the pluton during the long period of $17.1 \mathrm{Ma}$, that we do not consider as probable. The only possible source of K-feldspars of Carboniferous arkoses remain mountain (normal) granites of the older intrusive complex (OIC) of the Krušné hory Mts., exposed today in the Slavkov and Nejdek (NejdekEibenstock) part of the Karlovy Vary Massif.

The results of measurement of K-feldspars from the OIC and Permo-Carboniferous arkoses are not always identical in all aspects (see, for example, a comparison of recorded values in Table 2 and a correlation of the properties of K-feldspars of Permo-Carboniferous arkoses with the OIC of the Nejdek part of the Karlovy Vary Massif in Table 4). The more striking differences occurred, however, only in the case of the contents of albite-plagioclase component in the solid solution $\left(A b A n_{\text {solid }}\right)$. This parameter is higher in K-feldspars from arkoses and points to their lesser degree of exsolution. Such a disproportion can be explained by exposure of the upper part of the massif with a lesser grade of exsolution of the albite-plagioclase feldspars in the period of the Permo-Carboniferous sedimentation. Comparison of trace elements correlations in $\mathrm{K}$-feldspars of arkoses and the OIC, shows a most distinctive positive $\mathrm{Ba} / \mathrm{Sr}$ correlation in both, while a $\mathrm{Ba} / \mathrm{Rb}$ correlation practically does not exist. A negative $\mathrm{Sr} / \mathrm{Rb}$ correlation in the OIC K-feldspars is, in the case of arkoses, less noticeable. A positive $\mathrm{Sr} / \mathrm{Pb}$ correlation exists in K-feldspars from arkoses, as opposed to the OIC. However, it is necessary to take into account that the number of analyzed K-feldspars from the OIC is three times higher than that from arkoses. Some K-feldspars from arkoses have relatively increased $\mathrm{Rb}$ contents compared to K-feldspars in today's granites of the OIC (Figure 5c), which presupposes earlier magmatic phases. The character of K-feldspars shows a source from the OIC rocks, which must have already been denudated at the beginning of the 
Kladno Formation sedimentation, even though it might have concerned the rocks slightly different from the currently exposed rocks of the same granite massif.

The most eastern samples we have been studying (boreholes Beřovice Bř-5 and Martiněves Mt-1), occur at a distance of up to $90 \mathrm{~km}$ from today's Karlovy Vary Massif rim. Therefore, the horizontal and vertical range of the Carboniferous basins required huge volumes of the source porphyric granitoids, and it is questionable whether today's dimensions of the Karlovy Vary granite massif indicate that it was sufficiently large to supply them. However, it is necessary to realize that besides the granite feldspars, also other regional rocks took a considerable share in the sedimentary filling of the Carboniferous basins (Havlena \& Pešek 1975, Pešek 1994, 2004) and arkoses represent only a part of the basin filling material.

Table 4. Correlation coefficients of $A b A n_{\text {solid }}$ and trace elements of K-feldspars in Permo-Carboniferous arkoses and mountain granites (OIC) of the Nejdek part of the Karlovy Vary Massif (according to Jiránek 1983; $n=$ number of samples, $\mathrm{Ab}=$ albite, $\mathrm{An}=$ anorthite).

\begin{tabular}{|c|c|c|c|c|}
\hline \multicolumn{5}{|c|}{ Carboniferous arkoses $(n=41)$} \\
\hline $\mathbf{B a}$ & $\mathbf{S r}$ & $\mathbf{P b}$ & $\mathbf{R b}$ & \\
\hline+0.10 & -0.05 & -0.01 & +0.21 & $\boldsymbol{A b A n}_{\text {solid }}$ \\
\hline & +0.44 & +0.24 & -0.15 & $\mathbf{B a}$ \\
\hline & & +0.47 & -0.20 & $\mathbf{S r}$ \\
\hline & & & +0.04 & $\mathbf{P b}$ \\
\hline
\end{tabular}

\begin{tabular}{|c|c|c|c|c|}
\hline \multicolumn{5}{|c|}{ Mountain granites (OIC) } \\
of the Karlovy Vary Massif $(n=63)$ \\
\hline $\mathbf{B a}$ & $\mathbf{S r}$ & $\mathbf{P b}$ & $\mathbf{R b}$ & \\
\hline+0.10 & +0.13 & +0.18 & -0.01 & $\boldsymbol{A b A n}_{\text {solid }}$ \\
\hline & +0.54 & +0.17 & 0.00 & $\mathbf{B a}$ \\
\hline & & +0.05 & +0.55 & $\mathbf{S r}$ \\
\hline & & & +0.38 & $\mathbf{P b}$ \\
\hline
\end{tabular}

\section{Directions of transport of arkoses source material and their position in the sedimentary area of Permo-Carbonifer- ous basins}

While according to the current results of investigation of the West and Central Bohemian PermoCarboniferous basins the material should have been transported predominantly from S-SW (Žák et al. 2018), or N (Martínek et al. 2017), the results of our study of K-feldspars give evidence at least for the source of big arkoses feldspars to be NW in the area of today's Karlovy Vary Massif both for the whole time of sedimentation (314.2297.1 Ma; Moscovian-Asselian) and in the whole basin range up to a minimal distance of $90 \mathrm{~km}$ from the source (along the line Budyně nad Ohří Velvary - Kladno). The same direction of input (NW) was unambiguously confirmed by sedimentological study of the Nýrany Member sediments in the Kaznějov quarry with application of paleofluvial analyses (Lojka et al. 2016).

Primarily after the period between the Radnice and Nýřany members (Bolsovian - Asturian) in which the Leonian orogenetical phase occurred, fierce runoffs from the source area started, as it is proved by the whole fragments of mechanically disintegrated granite material in boreholes Kozolupy Kp-19 (69.10 m, Nýřany Member) and Vochov Vo6 (67.30 m, Týnec Formation) in the Plzeň Basin and even in the borehole Lotous Lo-6 (491.00 m, Týnec Formation) in the Kladno-Rakovník Basin. This sedimentation hiatus of tectonic origin is an important geological event starting large-scale bearing of the Karlovy Vary-Eibenstock Massif granites. It represents the strengthening of invasion of detritic material from the Krušné hory Mts. mountain granites into the Nýřany Member and Týnec Formation of the Plzeň and Manětín basins. However, the question of origin from the only NW source complicates a presence of detritic gold in both the Manětín and Plzeň basins (Klomínský et al. 1983). Particularly the mineralogical composition of heavy minerals (garnet, ilmenite, rutile, staurolite, tourmaline, monazite, native gold, but also cassiterite and topaz) points to the polygenetic origin from various rocks of the Krušné hory Mts. crystalline complex and the Barrandian Neoproterozoic and Paleozoic.

In view of the fact that arkoses do not fill up the whole sedimentary profile of the basins, explanation of the K-feldspar origin might be repeated runoffs of mechanically weathered granite material from the predecessor of today's Karlovy Vary Massif, while material of different composition also came from other directions. It was enabled by the NW direction of contribution, functioning in the bigger part of both basins for the whole period of sedimentation. Runnoffs of Permo-Carboniferous 
arkoses material must have been very fierce (bolson type of sedimentation), because sometimes whole blocks of unweathered granite material, whose disintegrated remains were found not only in the Plzen Basin but also in the varied runoff layer in the Kladno-Rakovník Basin (ca $82 \mathrm{~km}$ from the Karlovy Vary Massif), were transported.

\section{Notes on the genesis of kaolin deposits in arkoses of Permo-Carboniferous basins}

As opposed to Pouba \& Špinar (1954), Pouba (1959), Kužvart (1969), Kužvart et al. (1975) and Kužvart et al. (1983), who considered kaolin deposits in all four Upper Carboniferous - Lower Permian formations as uniform in genesis (kaolinization of arkoses immediately after sedimentation with possible continuation of the kaolinization processes in the Cretaceous up to the Miocene in some cases), Jiránek (1976), Jiránek et al. (1990) and Wilson \& Jiránek (1995) posited different ways for the genesis of the deposits of kaolins.

No kaolin deposits are known from the Radnice Member of the Kladno Formation (Duckmantian Bolsovian). The kaolinitization in the Nýrany Member (Asturian-Cantabrian; e. g. the deposits of Chlumčany, Orlík, Ledce, Obora, Tymákov) did not begin in the Carboniferous and occurred in near-surface conditions of the younger favourable climatic periods (Cretaceous-Miocene). On the other hand, the biggest Czech kaolin deposits of Kaznějov and Horní Bříza did not originate by kaolinization of sedimentary arkoses, but by sedimentation in the fluviolacustrine facies (a system of open lakes in the deeply cut, probably tectonically predisposed valley of NNE-SSW direction, presupposed by Pešek 1968 and Opluštil 2005) under oxidation conditions as conglomerates and sandstones with clay (kaolinitic) cement. In this process, kaolinite originated by pre-sedimentary kaolinization of feldspars ex situ, predominantly during transport. Kaolinization of the bigger clasts of feldspars might have occurred after sedimentation, while in the Cretaceous-Miocene deferrization of kaolins took place.

These conclusions were first evidenced by field observation (Jiránek 1976): (1) alternation of kaolin beds and non-kaolinized arkoses $(0 . \mathrm{X}-\mathrm{X} \mathrm{m})$ in the lower parts of the deposits of Horní Bříza and Kaznějov; (2) abundant intercalations of kaolinitic clays and siltstones (often of dark red colour), representing redeposited earlier kaolinized material, which would moreover have been a barrier to penetrating kaolinization solutions in the case of postsedimentary kaolinization (Lojka et al. 2016 found also interlayers of paleosoils); (3) findings of fresh feldspar clasts inside intensively kaolinized rocks, which Kužvart (1969) incorrectly considered as a proof of post-sedimentary kaolinization; and (4) geochemical characteristics, non-corresponding to the primary kaolinic profiles (irregular distribution of the major and trace elements in the vertical profile, common growth of trace elements, alkalis, and REE with the declining content of kaolinite; Jiránek 1982b). While the content of kaolinite in this type of sediments (i. e. in differently granular sandstones and conglomerates) does not change with the depth due to the fluent contribution of already kaolinized material, in the case of post-sedimentary kaolinization of arkoses the kaolinite content should distinctly decline with the depth.

These conclusions were later supported by electronic microscopy SEM (Jiránek et al. 1990). The sedimentary origin of kaolinite in the deposits of Horní Bříza and Kaznějov is shown by all-direction oriented isolated hexagonal plates of kaolinite, which in the case of kaolinitization in situ from feldspars would be arranged parallel and would have filled up the original space of feldspar in the shape of more or less hexagonally limited columns. In addition, the SEM images also show that non-abundant bigger clasts of fresh feldspars transported in the clay suspension were kaolinitized after sedimentation.

The genesis of the kaolins in the Týnec Formation (Barruelian-Saberian) and rare kaolin deposits in the Slaný Formation can hardly to be recognized due to the fact that no such deposit is exploited in present. Kaolins in arkosic sandstones of the Líně Formation (Stephanian C - Autunian) in the surroundings of Podbořany were partly kaolinized immediately after sedimentation and their kaolinization was completed in the Cretaceous up to the Miocene. 


\section{CONCLUSIONS}

K-feldspars in Permo-Carboniferous arkoses of the West and Central Bohemian basins were analysed by X-ray and AAS and the results were compared with known data for K-feldspars in granitoids of the Bohemian Massif. All K-feldspars samples studied both in the areal and the stratigraphic extent (Moscovian-Asselian) present an uniform type that corresponds to the K-feldspars of the older intrusive complex (OIC) of the Karlovy Vary Massif situated NW of the basins. Occasional strong runoffs of the granitoid material from that granite massif supported the K-feldspars of arkoses in the basins. Kaolinization of their feldspars took place differently in the particular formations; pre-sedimentary in the case of the deposits of Kaznějov and Horní Bř́za in the Nýřany Member, synsedimetary and post-sedimentary in the Líně Formation and post-sedimentary in the rest of deposits in the Nýrany Member of the Kladno Formation.

\section{REFERENCES}

Absolonová, E. \& Matoulek, M. 1978. Geochemická distribuce prvků v Karlovarském masívu. Sborník geologických věd, Ložisková geologie, mineralogie 17, 7-32.

Breiter, K. 2001. Phosphorus- and fluorine-rich granite system at Podlesí, 52-78. In Breiter, K. (ed) 2001. Phosphorus- and fluorine-rich granites, Podlesí, Czech Republic. Czech Geological Survey, Prague.

Breiter, K. 2012. Nearly contemporaneous evolution of the A- and S-type fractionated granites in the Krušné hory/Erzgebirge Mts., Central Europe. Lithos 151, 105-121.

Breiter, K., Knotek, P. \& Pokorný, V. 1991. Nejdek Granite Massif. Folia Musei rerum naturalium Bohemiae occidentalis, Geologica 33, 1-60.

Breiter, K., Sokolová, M. \& Sokol, A. 1991. Geochemical specialization of the tin-bearing granitoid massifs of NW Bohemia. Mineralium Deposita 26, 298-306.

Goldsmith, J.R. \& Laves, F. 1954. The microclinesanidine stability relations. Geochimica et Cosmochimica Acta 5, 1-19.

Havlena, V. \& Pešek, J. 1975. Litostratigrafické členění středočeského karbonu. Sborník Příroda (Plzeň) 11, 1-82.
Havlena, V. \& Pešek, J. 1980. Stratigrafie, paleogeografie a základní strukturní členění limnického permokarbonu Čech a Moravy. Sborník Př́iroda (Plzeř) 34, 1-144

Jiránek, J. 1976. Geological evidence of the genesis of the Horní Bř́za and Kaznějov kaolin deposits, 243-250. 7th Conference on Clay Mineralogy and Petrology in Karlovy Vary. Charles University, Prague.

Jiránek, J. 1979. Metodika studia draselných živců na rtg. difraktografu. Věstník Ústředního ústavu geologického 54, 225-232.

Jiránek, J. 1982a. Studium vyrostlic alkalických živců nejdecké části Karlovarského masívu. Sborník geologických věd, Geologie 3, 139-162.

Jiránek, J. 1982b. Studium granulometrie, geochemie a bělitelnosti kaolínů ve vertikálním profilu ložiskem Kaznějov. Sborník geologických věd, Ložisková geologie, mineralogie 24, 141-160 .

Jiránek, J. 1983. Geochemie alkalických živců Karlovarského masívu. Acta Universitatis Carolinae, Geologica 1983 (3), 216-236.

Jiránek, J., Müller, H.W. \& Schwaighofer, B. 1990. Genetic types of the kaolin deposits in the Bohemian Massif, 212-225. Thirty Years of geological cooperation between Austria and Czechoslovakia, Festive Volume. Geological Survey, Prague \& Geologische Bundesanstalt, Wien.

Jones, J.B., Nesbitt, R. W. \& Slade, P.G. 1969. The determination of the orthoclase content of homogenized alkali feldspars using the 201 X-ray method. Mineralogical Magazine 37, 489-496.

Klomínský, J., Jarchovský, T. \& Rajpoot, G. 2010. Atlas of plutonic rocks and orthogneisses in the Bohemian Massif: Saxothuringicum. 78 pp. Czech Geological Survey, Prague.

Klomínský, J., Jiránek, J., Malec, J., Novák, F., Odehnal. L. \& Veselovský, F. 1983. Zlatonosnost kontinentálního permokarbonu Českého masívu. Sborník geologických věd, Ložisková geologie, mineralogie 25, 111-186 .

Kukal, Z. 1984. Granitoidové plutony byly hlavním zdrojem živců permokarbonských sedimentů. Časopis pro mineralogii a geologii 29, 193-196.

Kužvart, M. 1969. Kaolin deposits of Czechoslovakia. Proceedings of the 23rd International geological congress 15, 47-73.

Kužvart, M., Křelina, B. \& Mátl, V. 1983. Kaolin, 126-156. In: Kužvart, M. (ed) Ložiska nerudních surovin ČSR. Charles University, Prague. 
Kužvart, M., Neužil, J., Pešek, J. \& Šindelář, J. 1975. Vznik a stáří ložisek kaolinu v Plzeňské pánvi. Sborník geologických věd, Ložisková geologie, mineralogie 17, 125-194.

Lange, H., Tischendorf, G., Pälchen, W., Klemm, I. \& Ossenkopf, W. 1972. Zur Petrographie und Geochemie der Granite des Erzgebirges. Geologie 21, 457-492.

Lojka, R., Rosenau, N.A., Sidorinová, T. \& Strnad L. 2016. Architecture, paleosols and cyclicity of the Middle-Late Pennsylvian proximal fluvial system (Nýřany Member, Pilsen Basin, Czech Republic). Bulletin of Geosciences91 (1), 111140.

Martínek, K., Pešek, J. \& Opluštil, S. 2017. Significant hiatuses in the terrestrial Late Variscan Central and Western Bohemian basins (Late Pennsylvanian - Early Cisuralian) and their possible tectonic and climatic links. Geologica Carpathica 68, 269-281.

Mašek, J. 1962. Petrografický výzkum arkóz v Plzeňské kamenouhelné pánvi. Věstník Ústředního ústavu geologického 37, 93-105.

Minařík, L. 1974. Krystalochemie koexistujicích živcových fází $v$ granitoidních horninách okrajového typu středočeského plutonu (šachta Radètice). Nepublikovaná zpráva, Československá akademie věd, Praha.

Minařík, L. 1975. Distribuce prvků v hlavních horninotvorných minerálech plutonitů. Časopis pro mineralogii a geologii 20, 185-199.

Minařík, L., Povondra, P. 1976. Geochemie draselných živců durbachitů Čertova Břemene. Studie Československé akademie věd 9, 7-63.

Neužilová, M. 1971. Twin of plagioclasses and triclinicity of alkali feldspars in the Bor Massif. Acta Universitatis Carolinae, Geologica 1970 (1), 1-10.

Neužilová, M. 1973a. Chemické složení alkalických živců. Časopis pro mineralogii a geologii 18, 309-318.

Neužilová, M. 1973b. Studium vyrostlic alkalických živců těchnického granodioritu ve středočeském plutonu. Sborník geologických věd, Geologie 25, 145-175.

Neužilová, M. 1983. Alkalické živce hornin kladrubského masívu. Sborník geologických věd, Geologie 36, 9-22.

Opluštil, S. 2005. Evolution of the Middle Westphalian river valley drainage system in Central Bohemia (Czech Republic) and its palaeographic implication. Palaeogeography, Palaeoclimatology, Palaeoecology 222, 223-258.

Opluštil, S., Schmitz, M., Cleal, J.C. \& Martínek, K. 2016. A review of Middle-Late Pennsylvanian west European regional substages and floral biozones, and their correlation to the Geological Time Scale based on new U-Pb ages. Earth-Science Reviews 154, 301-335.

Pešek, J. 1968. Geologická stavba a vývoj sedimentů plzeňské černouhelné pánve. Sborník Př́roda (Plzeñ) 2, 1-110.

Pešek, J. 1994. Carboniferous of Central and Western Bohemia (Czech Republic). 61 pp. Czech Geological Survey, Prague.

Pešek, J. 2004. Late Paleozoic limnic basins and coal deposits of the Czech Republic. Folia Musei rerum naturalium Bohemiae occidentalis, Geologica, Editio Specialis 1, 1-188.

Petránek, J. 1978. Byly variské plutony Českého masívu tak rychle obnaženy, že se staly zdrojem materiálu karbonských arkóz? Časopis pro mineralogii a geologii 23, 381-387.

Pivec, E. 1970. On the origin of phenocrysts of potassium feldspars in some granitic rocks of the Central Bohemian Pluton. Acta Universitatis Carolinae, Geologica 1970 (1), 11-25.

Pouba, Z. 1959. Některé geologické zákonitosti vzniku a rozmístění nerudných surovin v Plzeňské pánvi. Acta Universitatis Carolinae, Geologica 1959 (3), 343-361.

Pouba, Z. \& Špinar, Z. 1954. Stratigrafické poměry okolí kaolínového ložiska u Chlumčan (jižní část plzeňské pánve). Věstník Ústředního ústavu geologického, 29, 145-158.

Rojík, P. 2006. Tin deposits at Přebuz and Rolava in the Krušné hory Mts/Erzgebirge, Czech Republic: Classic localities and new challenges. Journal of Geological Society 50, 157-165.

Štemprok, M. 1986. Petrology and geochemistry of the Czechoslovak part of the Krušné hory Mts pluton. Sborník geologických věd, Ložisková geologie, mineralogie 27, 111-156.

Thomas, R., Förster, H.J. \& Tischendorf, G. 1991. PTX-signatures of Hercynian oreproducing granites, Erzgebirge, Germany, 231-234. In: Pagel, L.M. \& Leroy, J.A. (eds) Source, Transport and Deposition of Metals, Rotterdam.

Vlašímský, P. 1986. Příspěvek k diskusi o karbonských arkózách a hloubce denudace variských plutonů. Časopis pro mineralogii a geologii 31, 429-434. 
Jiří Jiránek, Josef Klomínský \& Jana Jiránková, Source of K-feldspars and kaolinitization in arkoses of West and central Bohemian continental Permo-Carboniferous

Wilson, I.R. \& Jiránek, J. 1995. Kaolin deposits of the Czech Republic and some comparisons with south-west England, 357-362. Annual Conference of the Ussher Society, January 1995, Proceedings of the Ussher Society 8.

Žák, J., Svojtka, M. \& Opluštil, S. 2018. Topographic inversion and changes in the sediment routing systems in the Variscan orogenic belt as revealed by detrital zircon and monazite. $\mathrm{U} / \mathrm{Pb}$ geochronology in post-collisional continental basins. Sedimentary Geology 377, 63-81. 